\title{
Implementasi Media Pembelajaran Pengenalan Jaringan Komputer dengan Adobe Flash CS 3 Professional
}

\author{
Ariansyah $^{1}$, Nurmayanti $^{2}$, Gardini Emsco Sumbadri $^{3}$ \\ ${ }^{123}$ STMIK Prabumulih \\ Jl. Patra No. 50 Kelurahan Sukaraja Kecamatan Prabumulih Selatan Kota Prabumulih \\ e-mail : ayielubai@gmail.com, ynurma911@gmail.com, gardiniemsco@gmail.com
}

\begin{abstract}
In the world of education today the role of computers has become very much needed, almost all schools have used computer aids for administrative processes and other matters. This research is motivated by the lack of use of computers as a learning medium in SMK Negeri 1 Prabumulih, the delivery and explanation of the material still use previous methods such as, using books and explaining on the board. The purpose of this research is to make the Application of Learning Media for Introduction to Computer Networks for Multimedia students using Adobe Flash CS 3 Professional. The results of research in making instructional media are carried out through a process of analysis, production design, implementation, and evaluation. In the analysis process, edutainment aspects that must be present in the learning media are obtained, including an attractive, interactive display, using sound effects, pictures and videos of learning material. Furthermore, the learning media are packaged in a CD. So hopefully with this learning media, the learning system at SMK Negeri 1 Prabumulih can be even better.
\end{abstract}

Keywords - Learning Media, Multimedia, Computer Network

\begin{abstract}
ABSTRAK
Di dunia pendidikan sekarang ini peranan komputer sudah menjadi yang sangat di butuhkan, hampir semua sekolah telah menggunakan alat bantu komputer untuk proses administrasi dan urusan lainnya. Pada penelitian ini dilatar belakangi oleh belum adanya pemanfaatan komputer sebagai media pembelajaran di SMK Negeri 1 Prabumulih, penyampaian dan penjelasan materi masih menggunakan cara-cara terdahulu seperti, menggunakan buku dan menjelaskan di papan tulis. Adapun maksud dari penelitian ini adalah membuat Aplikasi Media Pembelajaran Pengenalan Jaringan Komputer untuk siswa Multimedia menggunakan Adobe Flash CS 3 Professional. Hasil penelitian pembuatan media pembelajaran dilakukan melalui proses analisis, desain produksi, implementasi dan evaluasi. Dalam proses analisis didapat aspek edutainment yang harus ada dalam media pembelajaran diantaranya tampilan yang menarik, bersifat interaktif, menggunakan efek suara, gambar dan ada video dari materi pembelajaran. Selanjutnya media pembelajaran yang dibuat dikemas dalam bentuk CD. Sehingga diharapkan dengan adanya media pembelajaran ini sistem belajar di SMK Negeri 1 Prabumulih bisa lebih baik lagi.
\end{abstract}

Kata Kunci : Media pembelajaran, Multimedia, Jaringan komputer 


\section{Pendahuluan}

Media pembelajaran merupakan suatu alat atau perantara yang berguna untuk memudahkan proses belajar dan mengajar, dalam rangka mengefektifkan komunikasi guru dan siswa. Hal ini sangat membantu guru dalam mengajar dan memudahkan siswa menerima dan memahami pelajaran. Proses ini membutuhkan guru yang mampu menyelaraskan antara media pembelajaran dan metode pembelajaran. Di dunia pendidikan sekarang ini peranan komputer sudah menjadi sangat

dibutuhkan, hampir semua sekolah telah menggunakan alat bantu komputer untuk memproses adminisrasi dan urusan lainnya [1]. Begitu pula pada SMK Negeri 1 Prabumulih, komputer sudah menjadi bagian dalam proses pembelajaran. Namun, komputer belum secara maksimal dipergunakan untuk menjadi alat bantu dalam pengajaran.

\section{Metode Penelitian}

Dalam pemecahan masalah Penulis berpedoman pada rekayasa perangkat lunak untuk mempermudah proses perancangan penulisan menggunakan metode UCD (User Centered Design). UCD (User Centered Design) merupakan hal yang baru dalam metode pengembangan sistem. Yaitu perancangan berbasis pengguna, UCD digunakan untuk menggambarkan filosofi perancangan. Konsep dari UCD adalah user sebagai pusat dari proses pengembangan sistem, dan tujuan/sifatsifat, konteks dan lingkungan sistem semua didasarkan dari pengalaman pengguna. UCD adalah tentang partisipasi dan pengalaman manusia dalam perancangan. Pengguna adalah orang yang menggunakan sistem. Pengguna yang langsung menggunakan sistem biasa disebut pengguna akhir (end user).

Adapun yang menjadi prinsip kerja dalam UCD (User Centered Design) adalah sebagai berikut Secara garis besar model UCD.

a. Fokus Pada Pengguna

Perancangan harus terkoneksi langsung dengan pengguna akhir atau calon pengguna melalui wawancara, survey dan workshop pada saat perancangan. Tujuannya adalah untuk memahami kondisi, karakter dan sikap pengguna serta karakteristiknya. Aktifitas utamanya mencakup pengambilan data, analisis dan integrasinya kedalam informasi, perancangan dari pengguna tentang karakteristik tugas, lingkungan teknis di dalam organisasi. 
b. Perancangan Terintegrasi

Perancangan harus mencakup antar muka pengguna, sistem bantuan, dukungan teknis serta prosedur untuk instalasi dan pengaturan konfigurasi.

c. Perancangan Interaktif

Sistem yang sedang dikembangkan harus didefinisikan dirancang, dan dites berulangkali. Berdasarkan hasil tes kelakuan dari fungsi, antarmuka, sistem bantuan, dokumentasi pengguna dan pendekatan dalam pelatihannya.

\section{Hasil dan Pembahasan}

Tahap implementasi merupakan tahap penerapan sistem supaya dapat dioperasikan.

\subsection{Implementasi Tampilan Awal Media Pembelajaran}

Pada halaman ini tidak ada button khusus yang digunakan, button dan background menjadi dalam satu bagian untuk masuk ke dalam menu pengantar materi.

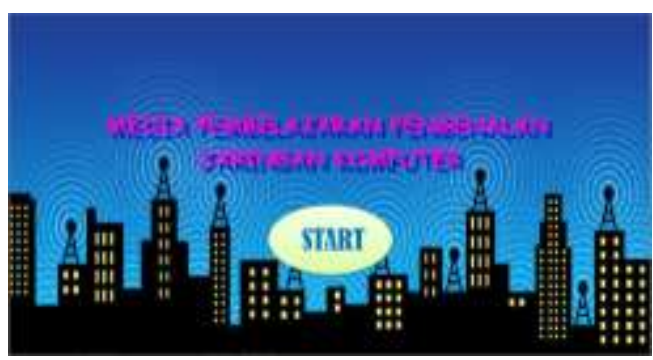

\section{Gambar 1. Tampilan Halaman Utama}

\subsection{Tampilan Pengantar Materi}

Pada halaman menu pengantar materi ini merupakan halaman penjelasan awal materi yang mempunyai button menuju halaman menu materi yang isinya terdapat beberapa button untuk masuk ke materi masing-masing.

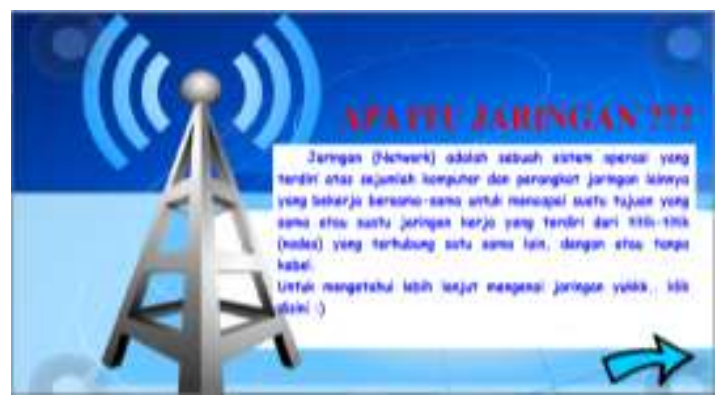

Gambar 2. Tampilan Pengantar Materi

\subsection{Tampilan Menu Materi}

Pada halaman menu materi ini merupakan halaman menuju isi dari materi media pembelajaran berupa isi pembahasan, penjelasan, gambar dan video dari materi jaringan komputer.

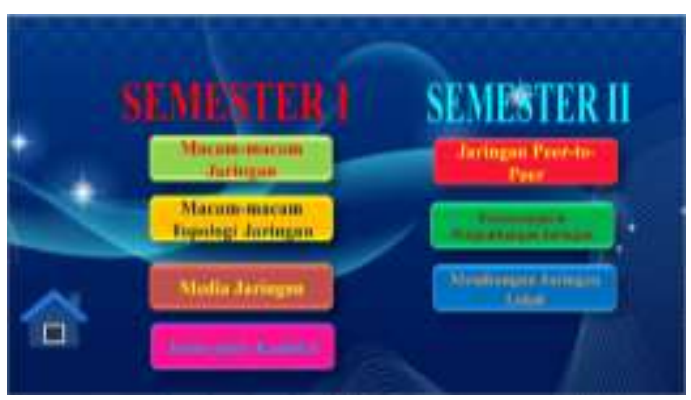

Gambar 3. Tampilan Menu Materi

\subsection{Tampilan Halaman Pengenalan dan}

\section{Materi Jaringan Komputer}

Pada halaman ini berisi beberapa tombol menu diantaranya ada button menu PAN jika di klik menuju isi materi dari PAN, lalu ada button LAN jika di klik menuju isi materi dari LAN, lalu ada button MAN jika diklik menuju isi materi 
dari MAN, dan ada button WAN jika diklik menuju isi materi dari WAN, dan juga ada button home jika di klik menuju halaman menu materi.

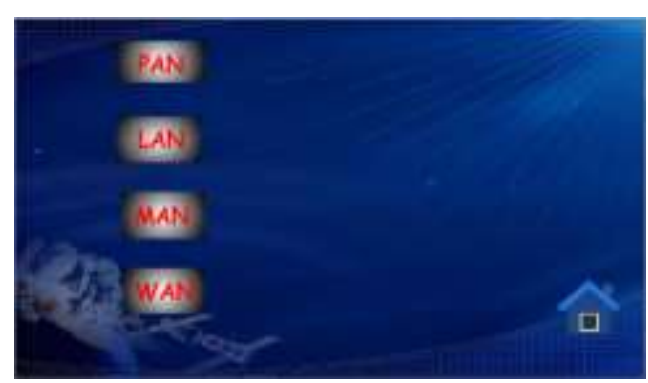

Gambar 4. Tampilan Halaman Pengenalan dan Materi Jaringan Komputer

\subsection{Tampilan Menu Materi Macam- \\ Macam Topologi Jaringan}

Menu berikut ini akan memberikan beberikan beberapa bentuk dari topologi jaringan. Dan bila di klik akan diberikan uraian mengenai topologi tersebut.

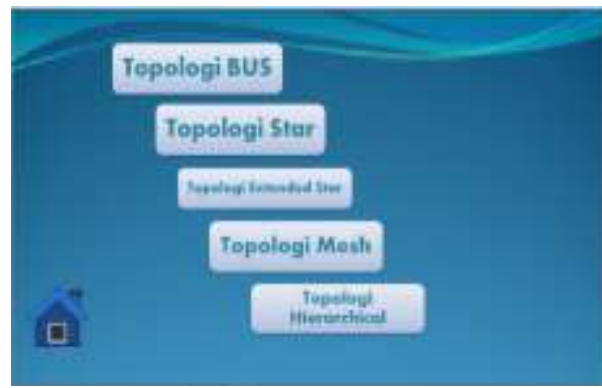

Gambar 5. Tampilan Menu Materi Macam-Macam Topologi Jaringan

\subsection{Tampilan Menu Materi Media Jaringan}

Selanjutnya menu yang memberikan uraian mengenai media transmisi yandapat digunakan pada jaringan, yakni berupa kabel atau wireless.

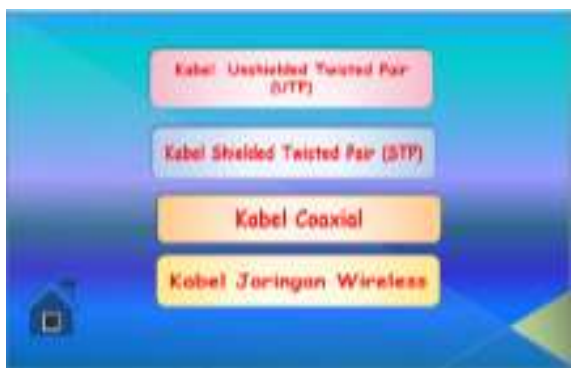

\section{Gambar 6. Tampilan Menu Materi Media Transmisi Jaringan}

\section{KESIMPULAN}

Dari hasil pembahasan ini kesimpulan yang dapat di ambil oleh penulis dalam pembuatan aplikasi media pembelajaran, yaitu :

1. Penelitian yang dilakukan merupakan penelitian pengembangan. Tahap pengembangan dalam penelitian ini meliputi tahap analisis, tahap perancangan media pembelajaran dan tahap validasi.

2. Penelitian yang dilakukan menghasilkan CD interaktif aplikasi media pembelajaran pengenalan jaringan komputer untuk siswa SMK kelas $\mathrm{X}$ jurusan multimedia pada SMK Negeri 1 Prabumulih. 


\section{DAFTAR PUSTAKA}

[1] Fitria, F., \& Ya, M. A. E. (2017). Model Analisis Sistem Aplikasi Media Ajar Online Sebagai Strategi Penguatan Daya Saing Sumber Daya Manusia. E-Proceedings KNS\&I STIKOM Bali, 43-48.

[2] Daryanto., 2011, Belajar Komputer Animasi Macromedia Flash, CV. Yrama Widya, Bandung.

[3] Daryanto., 2012, Media Pembelajaran, PT. Sarana Tutorial Nurani Sejahtera, Bandung.

[4] Irawan., 2013, Jaringan Komputer Untuk Orang Awam, Maxikom, Palembang.

[5] Maseleno, Andino., 2010 Modul Aplikasi Perancangan Sistem, Andi Offset, Jakarta.

[6] Prasetyo, Eko., 2011, Pemrograman Web PHP dan MySQL, Graha Ilmu, Jakarta.

[7] Sofana, Iwan., 2013, Membangun Jaringan Komputer, Informatika Bandung, Bandung.

[8] Sugiarti, Yuni., 2011, Analisis \& Perancangan UML ( Unified Modelling Language) Generated VB 6, Graha Ilmu, Jakarta.

[9] Wulansari, Bekti \& Widada., 2015 Cara Mudah membuat Media Pembelajaran Game Kuis
Menggunakan Flash, Gava Media, Yogyakarta.

[10] Wijang Widhiarso, Jessianti \& Sutini 2007, Metode UCD (User Centered Design) Untuk Rancangan Kios Informasi Studi Kasus : Rumah Sakit Bersalin XYZ, Palembang 